\title{
Rio+20: What is 'The Future We want?'
}

\section{Ong Suan Ee}

\section{Synopsis}

The world's biggest summit on environment and development in 20 years wrapped up on 22 June 2012 in Rio de Janeiro, Brazil. Has the outcome of Rio+20 managed to meet its promise?

\section{Commentary}

The Rio+20 United Nations Conference on Sustainable Development (UNCSD) in Rio de Janeiro on 19-24 June 2012 brought together world leaders, government officials, and civil society and private sector representatives who sought the best ways to work towards achieving a global 'green economy', poverty eradication and sustainable development.

Long before the conference even began, however, there was considerable pessimism that Rio+20 would amount to anything more than another elite talk-shop. The outcome of this massive multilateral effort appears to vindicate this gloomy forecast. What did Rio+20 achieve?

\section{One Step Forward}

There were several positive outcomes, the most highprofile of which is the decision to set up Sustainable Development Goals (SDGs) next year. Unlike the Millennium Development Goals (MDGs), the SDG topics are broader and will include all three aspects of sustainable development - economic, social and environmental. The SDGs also seek to perpetuate momentum in international development work beyond the poverty-eradicating mission of the MDGs, which will lapse in 2015 .

Rio+20 also saw other accomplishments, particularly in terms of financial pledges towards sustainable development. Governments, private companies and multilateral agencies committed themselves to voluntary pledges worth US $\$ 513$ billion towards projects aimed at reducing fossil fuel use, improving renewable energy sources, conserving water, and assuaging poverty.

Eight international development banks, including the Asian Development Bank (ADB), World Bank (WB) and Intra-American Development Bank (IADB) agreed to invest US $\$ 175$ billion to sustainable public transport systems over the next decade. Private sector companies pledged to contribute US $\$ 50$ billion to an UN-backed plan to provide energy to the entire global population by 2030.

While these promises should not be taken lightly, it remains to be seen to what degree these pledges will be fulfilled, particularly in a time of persistent global economic uncertainty.

\section{And Two Steps Back?}

To its credit, the 238-paragraph 'The Future We Want' outcome document attempts to call attention to a cornucopia of the most pressing development issues, ranging from food security and poverty eradication to small island developing states and mining. However, its hope to address all these challenges while upholding states' 'common but differentiated responsibilities' and being 'people-centred and inclusive, providing opportunities and benefits for all citizens and all countries' seems to err on the side of breadth, while lacking necessary depth and conviction.

The language of the document is also weak and evasive. It repeatedly "reaffirms", "recognises", "emphasises", and "strongly urges", but "commits" to little. The document is further debilitated by the deletion of several major commitments, including specific targets for cutting carbon emissions and the proposed establishment of a US\$30 billion fund for sustainable environmental activities in developing countries. Instead, there was a promise to enhance funding for this cause, but the specifics were left to future discussions.

The notable non-attendance of US President Barack Obama, UK Prime Minister David Cameron and German Chancellor Angela Merkel despite their having gone to Mexico for the G20 summit the previous week, reflects that some of the world's most advanced countries remain preoccupied with other more immediate priorities such as the Eurozone crisis rather than environmental and developmental concerns.

The conference has also come under fire for its underpinning 'green economy' concept. Much of Rio+20 were focused on making the Third World a part of the 'green economy', an effort led by developed Western nations. The UN Environment Programme (UNEP) defines a green economy as one that 'results in improved human well-being and social equity, while significantly reducing environmental risks and ecological scarcities' that is to say, a low carbon, resource efficient and socially inclusive economy.

A green economy aims to create jobs and profits through low-carbon, resource-saving businesses. Part of this involves potentially placing economic value on environmental services provided by nature and to incorporate environmental factors alongside GDP as a measure of national well-being. This approach has drawn significant flak for attempting to "commodify and financialise nature'. Critics have also argued that today's green economy policies only make minor carbon reductions at a very high cost and promise millions of jobs with large subsidies. This in turn raises costs for the rest of the economy and causes an equal or greater number of job losses elsewhere.

Also, the green economy framework has been criticised for not considering the most immediate concerns of the developing world, including malnourishment; the burden of tropical, communicable, and neglected

Continued in page 76 
Continued from page 74 diseases; and access to clean drinking water, sanitation, and electricity. According to Dr. Bjorn Lomborg of the Copenhagen Consensus Centre, $13 \%$ of all deaths in the developing world are still attributable to air and water pollution.

\section{How to Achieve 'The Future We Want?'}

Several experts including Jeffrey Sachs of Columbia University's Earth Institute have argued that the most important outcome of Rio+20 is not a document or treaty, but that it catalyses a global call to action, spearheaded by public awareness of sustainable development and climate change issues and a desire to make these priorities central to global thinking and action.

This is already taking place as a 'patchwork' climate change and sustainable development architecture emerges. Green initiatives in individual countries, communities and corporations are prospering. Solar and wind capacity is increasing across Europe. The US is increasingly using natural gas in place of gasoline and coal, and the energy potential of shale gas is being tapped with growing zeal. China is replanting trees in deforested areas and supporting local emissions-trading initiatives. Most importantly, this groundswell of bottom-up effort will continue to mature - with or without the support of international accord.
For Rio+20's top-down approach to stay relevant within this matrix of disparate yet connected developments, it is imperative that international governing bodies determine precisely what they want the future to look like.

As the global sustainable development landscape changes, the UN needs to definitively decide whether or not it wants to be a key actor and driver of the change that is already taking place on the ground. Should the UN's vision of the future it wants remain ambiguous and therefore directionless, it stands to lose not just credibility, but also valuable opportunities for collaboration with dynamic and forward-looking interest groups who seek the very same thing - a sustainable future for all.

Ong Suan Ee is Senior Research Analyst at the Centre for Multilateralism Studies, S. Rajaratnam School of International Studies, Nanyang Technological University, Singapore.

(Source: RSIS Commentaries, S. Rajaratnam School of International Studies; Published on 26 June 2012, No. 110/2012; URL: www.rsis.edu.sg/publications/ perspective/RSIS1102012.pdf) 